\title{
Skryfprobleme met Chemieterme
}

\author{
D.F. Louw, Inligtings- en Navorsingsdienste, WNNR, Posbus 395, Pretoria 0001
}

\section{DIE UITGANG $-I N$ IN ENGELS}

Selfs met 'n oppervlakkige kyk deur die Chemiewoordeboek blyk dit dat 'n betreklik eenvormige patroon bestaan vir die vertaling in Afrikaans van chemieterme wat in Engels op -in eindig. Die volgende voorbeelde illustreer dat die Engelse -in in Afrikaans -ien word: -

$\begin{array}{ll}\text { actin: } & \text { aktien } \\ \text { bactericidin: } & \text { bakterisidien } \\ \text { chymotrypsin: } & \text { chimotripsien } \\ \text { daidzin: } & \text { daidsien } \\ \text { erepsin: } & \text { erepsien } \\ \text { formonetin: } & \text { formonetien }\end{array}$

Dan is daar terme wat in Engels soms met -in en soms met -ine geskryf word. Voorbeelde hiervan is die volgende: -

$\begin{array}{ll}\text { amin(e): } & \text { amien } \\ \text { creatin(e): } & \text { kreatien } \\ \text { glycerin(e): } & \text { gliserien } \\ \text { harmin(e): } & \text { harmien } \\ \text { neurin(e): } & \text { neurien } \\ \text { vitamin(e): } & \text { vitamien }\end{array}$

Ook hier is die patroon deurgaans dat die uitgang -in (of -ine) uit Engels in Afrikaans met -ien vertaal word.

Daar is egter 'n klein aantal opvallende uitsonderings soos die volgende:-

aquamarine:

akwamaryn (halfedelsteen of kleur)

mandarin(e):

propine (propyne):

mandaryn (kleurstof)

propyn (met driedub-

belbinding)

serpentine: $\quad$ serpentyn: (soort asbes)

Wanneer in hierdie gevalle na die spelling in Duits gekyk word (Aquamarin, Mandarine, Propin, Serpentin), blyk dit dat die -yn-vorm afwesig is. In Nerderlands kom egter akwamarijn (of aquamarijn), mandarijn, propijn, en serpentijn voor, wat die -ynuitgang in Afrikaans verklaar. Daar kan volledigheidshalwe darem net vermeld word dat die spelling propyne in Engels die voorkeur geniet omdat dit strook met die voorkoms van die driedubbelbinding in die chemiese struktuur.

By 'n beperkte aantal terme loop die vertaler hom in ' $n$ chemiese probleem vas as hy die Engelse -in in Afrikaans met -ien wil weergee. Voorbeelde hiervan is die volgende:

* Kinin kan nie in Afrikaans met kinien vertaal word nie, want dit is reeds die vertaling vir quinine. Eersgenoemde verbinding is ' $n$ basiese peptied wat farmakologies aktief is by allergiese reaksies, en laasgenoemde (wat in Nederlands chinine of kinine en in Duits Chinin genoem word, en dus nie met kinin/Kinin verwar kan word nie) is die bekende alkaloïed uit sinkonabas. Daar word derhalwe voorgestel dat die peptied se naam in Afrikaans ook kinin geskryf word, en dus ook bradykinin, sitokinin en villikinin, wat die chemiese probleem uitskakel.

* Serine (die aminosuur) word in Afrikaans met serien vertaal. Dus kan cerin nie ook in Afrikaans serien geskryf word nie. In laasgenoemde geval word voorgestel dat in Afrikaans serin geskryf word waar die koolwaterstofmengsel bedoel word wat onder andere in die Baikalmeer en in Utah, VSA, voorkom. (In Engels word die koolwaterstofmengsel ook earth wax, cerosin of ceresin genoem. Ceresin en cerosin word in Afrikaans onderskeidelik liefs ook as seresin en serosin vertaal om die analogie met serin te behou).

* Olivine (in Engels) is 'n magnesiumystersilikaat wat in Afrikaans as olivien bekend staan. Hierteenoor is olivin (Engels) ' $n$ aglikoon (met drie gekondenseerde ringe) wat in die antibiotikum olivomisien voorkom. Om verwarring te vermy word voorgestel dat die aglikoon in Afrikaans olivin genoem word, en nie olivien soos die normale skryfwyse dit sou wou hê nie.

* Cyclamine (Engels) is 'n sikliese stikstofbasis (soos pirrool) wat in Afrikaans met siklamien (dus 'n saamtrekking van sikliese amien) vertaal kan word. Cyclamin (Engels) - 'n derivaat van malvidienchloried - is egter 'n saponien uit die wortels van die siklaam. Om verwarring met siklamien te vermy, word voorgestel dat die saponien in Afrikaans siklamin genoem word. 'n Alternatiewe oplossing sou wees om cyclamine in Afrikaans met sikloamien te vertaal (na analogie van sikloparaffien en sikloöktanol-laasgenoemde met 'n deelteken en nie met 'n koppelteken nie!) Saamtrekkings soos in cyclamine (en cyclammonium) is skaars in Engels en die siklo-vorm in Afrikaans kan eintlik liewer vir cyclo-terme in Engels gereserveer word.

* Hoewel die Engelse term cerulenin in Afrikaans met serulenien vertaal sal word, moet die ander naam daarvoor, helicocerin, in Afrikaans liefs as helikoserin geskryf word (en nie helikoserien nie, want dit is nie 'n serienderivaat nie).

Heelparty afwykings van die gebruiklike wyse waarop Engelse terme op -in in Afrikaans vertaal word, kom in die Suid-Afrikaanse Buro vir Stan- 
daarde se publikasie SABS $075-1981$ voor. Die afwykings is die gevolg van 'n reël wat hulle vir die skryf van gewone name vir plaagdoders en landbouchemikalieè neergelê het, naamlik dat -in (behalwe by antibiotika) in Afrikaans ook met -in geskryf moet word. Slegs gewone name wat in Engels op -ine of. -yne eindig, word in Afrikaans met -ien geskryf. As motivering hiervoor dien die uitgangspunt dat 'die spelling en styl van die vertaalde (Afrikaanse) naam op die uitspraak of skrifbeeld van die oorspronklike (Engelse) gewone naam' moet berus.

Voorbeelde hiervan is die volgende:-

\begin{tabular}{|c|c|c|}
\hline & Engels & Afrikaans \\
\hline (a) & aldrin & aldrin \\
\hline & $\begin{array}{l}\text { allethrin } \\
\text { carboxin }\end{array}$ & $\begin{array}{l}\text { alletrin } \\
\text { karboksin }\end{array}$ \\
\hline & cismethrin & sismetrin \\
\hline (b) & $\begin{array}{l}\text { mesoprazine } \\
\text { oxytetracycline } \\
\text { procyazine }\end{array}$ & $\begin{array}{l}\text { mesoprasien } \\
\text { oksitetrasiklien } \\
\text { prosiasien }\end{array}$ \\
\hline & methroprotryne & metroprotrien \\
\hline
\end{tabular}

Van bostaande vertaalde vorms is dié in groep (b) volgens die Chemiewoordeboek se skryfstelsel aanneemlik. Die korrektheid/wenslikheid van die ander skryfvorms moet egter bevraagteken word. Ten opsigte van aldrin-wat volgens die Chemiewoordeboek in Afrikaans aldrien is, kan byvoorbeeld gevra word of en hoe daar tussen die chemiese stof en die plaagdoder onderskei moet word.

Met die transliterering uit Engels in Afrikaans van die terme in groep (a) word heeltemal by die stelsel in die Chemiewoordeboek gehou, want $t h r$ word $t r$, car word kar, ox word oks en cis word sis. Die afwyking ten opsigte van die -in is egter hier opvallend. By die terme in groep (b) word die erkende translitereerbeginsels konsekwent toegepas, maar by methroprotryne in groep (c) word die gebruiklike uitgang -yn nie in die Afrikaanse vertaling gebruik nie. Hierdie aspekte verdien besinning deur die betrokkenes.

\section{DIE UITGANG $-A L$ OF $-A A L$ IN} AFRIKAANS?

Die volgende lysie terme wat op -al of -aal eindig, is uit die Chemiewoordeboek saamgestel-met die Duitse skryfwyse ter vergelyking daarby:-

$\begin{array}{lll}\text { Engels } & \text { Afrikaans } & \text { Duits } \\ \text { acetal } & \text { asetaal } & \text { Acetal } \\ \text { barbital } & \text { barbital } & \text { Barbital } \\ \text { citral } & \text { sitraal } & \text { Citral } \\ \text { cuminal } & \text { kuminaal } & \text { Cuminal } \\ \text { ethanal } & \text { etanaal } & \text { Ethanal } \\ \text { geranial } & \text { geraniaal } & \text { Geranial } \\ \text { methylal } & \text { metilal } & \text { Methylal } \\ \text { pyridoxal } & \text { piridoksaal } & \text { Pyridoxal } \\ \text { veronal } & \text { veronaal } & \text { Veronal }\end{array}$

Die volgende opmerkings is ter sake:-

* Barbital-sinoniem met barbitoon-is 'n barbituursuurderivaat, dus 'n pirimiedienverbinding, en wel die 5,5-diëtielsubstitusieverbinding.
* Metilal staan ook bekend as dimetoksimetaan $\left(\mathrm{CH}_{3} \cdot \mathrm{O} . \mathrm{CH}_{2} \cdot \mathrm{O} \cdot \mathrm{CH}_{3}\right)$.

* Veronal is 'n handelsmerk (volgens die Merck Index) wat vir 5,5-diëtielbarbituursuur gebruik word. Dit behoort dus in die eerste plek nie in die Chemiewoordeboek opgeneem te gewees het nie, en moet in elk geval met 'n hoofletter geskryf word en nie vertaal word nie. Die vertaalde vorm met -aal moet dus verval.

* Al die ander terme is benamings vir aldehiede (met 'n CHO-groep) of vir alkieleters van aldehiedhidrate (met die groep - $\mathrm{CH}(\mathrm{OR})_{2}$ daarin).

Uit dié voorbeelde wil dit voorkom asof aldehiede en hul derivate in Afrikaans met -aal geskryf word en die ander terme met -al. In Engels word al die terme in hierdie groepe met -al geskryf, en so ook in Duits, maar in die laasgenoemde geval word dit met 'n lang $a$-klank uitgespreek - naastenby soos -aal in Afrikaans.

Verreweg die meeste chemieterme wat in Engels op - $a l$ eindig, verwys na aldehiede en hul derivate. Dit lyk egter na 'n onnodige komplikasie om in Afrikaans met -aal en -al tussen aldehiede en niealdehiede te onderskei - 'n beginsel wat nòg in Engels nòg in Duits geld. Hoe ingewikkeld die saak kan word, blyk uit die volgende voorbeelde (waarby slegs die Engelse terme gegee word):-

carbromal-'n karbamied

chlorthal-dimethyl-'n ester van tetrachloortereftaalsuur

nitral - 'n propaandioldinitraat

Die hele skryfstelsel sal oneindig eenvoudiger (en hanteerbaarder vir nie-chemici) wees indien alle chemieterme wat in Engels en Duits op -al eindig in Afrikaans met -aal geskryf word. Daar word dan ook voorgestel dat hierdie skryfwyse algemeen aanvaar word (ook by die hersiening en uitbreiding van die Chemiewoordeboek), tensy gegronde besware daarteen ingebring word. So 'n besluit sal meebring dat die spelling van barbital en metilal in die Chemiewoordeboek verander moet word, maar dat die groot getal terme op -aal onveranderd bly. Die volgende spellings sal dan aan hierdie reël voldoen:-

amobarbitaal

axeroftaal ('n sinoniem vir vitamien A)

barbitaal

bensaalchloried ('n tolueenderivaat)

bourbonaal ('n sinoniem vir etielvanillien)

butetaal ('n barbituursuurderivaat)

chloortaalmetielester

etielprotaal ('n sinoniem vir etielvanillien)

fosfatidaal ('n gliserienderivaat)

heksanaal (en al dergelike benamings vir aldehiede)

karbromaal

ketaal

ketoksaal

kopaal ('n boomhars)

metilaal

neraal ('n sitraal)

nitraal

retinaal ('n sinoniem vir vitamien A-aldehied)

vanillaal ('n sinoniem vir etielvanillien) 
Op die meeste reëls is daar ' $n$ uitsondering of twee. Hier moet ook een aangestip word, naamlik boral, waarvan die -al daarop dui dat dit 'n derivaat van aluminium (simbool: $A l$ ) is. Hier is dit wenslik om die uitgang -al te behou. Bensaldoksiem ('n sametrekking van bensaldehied en oksiem) is nie in stryd met die reël nie; net so min as bensaldehied self wat ' $n$ aldehiedderivaat van benseen is. Eweneens sal bensalisarien, bensalkonium en bensaldasien geskryf word, maar bensaalasetoon en bensaalgroen. ( $\mathrm{Al}$ voldoen terme soos metaal, distaal en hormonaal ook oënskynlik aan die 'vertaalreël' wat hierbo voorgestel is, val hulle nie binne die groep terme wat hier ter sprake is nie.) 